\title{
KONTRIBUSI DOA MISTIK KARL RAHNER BAGI KALANGAN REFORMED DI ERA PASCAKEBENARAN
}

Firdaus Salim

STT Reformed Indonesia daus1297@gmail.com

\begin{abstract}
Reformed conservatives tend to be suspicious and hostile to personal and subjective religious experience. Based on the works of John Calvin, Reformed theology is deemed to exclusively emphasize intellect and rationality. As the world is now facing a post-truth era, Reformed conservatives need to be aware that such era, which is generally understood in the political context, has also affected the dynamics of faith. The post-truth era has made rational and objective facts become less appealing. The subjective elements which involve mystery and awe have now deserved attention. In facing such an era, this article aims to show that the works of Calvin, especially Institutes and his commentary on the book of Psalms, are not hostile to personal religious experience. In fact, the works of Calvin are inseparable from mystical writings and even shows an openness to religious experience. Given such openness, Karl Rahner's mystical prayers can instill the elements of mystery and awe in the faith of Reformed conservatives.
\end{abstract}

Keywords: post-truth, mystic, mysticism, Calvin, Karl Rahner

\begin{abstract}
Abstrak
Kalangan Reformed konservatif cenderung bersikap curiga dan bermusuhan terhadap berbagai pengalaman iman yang sifatnya pribadi dan subjektif. Teologi Reformed yang berakar pada karya Calvin telah dianggap mengutamakan akal budi dan rasionalitas semata. Mencermati perkembangan zaman, kalangan Reformed perlu menyadari bahwa dunia sedang berhadapan dengan sebuah era, yakni era pascakebenaran. Era pascakebenaran, yang sering ditempatkan hanya dalam konteks politik, ternyata mempunyai dampak pula terhadap dinamika iman. Era pascakebenaran ini telah membuat rasionalitas dan hal-hal yang sifatnya objektif menjadi kurang lagi menarik. Unsur misteri dan kekaguman dalam iman yang sifatnya subjektif justru perlu mendapatkan tempatnya.
\end{abstract}


Menghadapi era yang demikian, makalah ini bertujuan untuk menunjukkan bahwa karya Calvin, terutama Institutes dan tafsiran Mazmurnya, tidak bersikap bermusuhan terhadap pengalaman pribadi. Justru karya Calvin tidaklah lepas dari pengaruh tulisan mistik dan bahkan menunjukkan keterbukaan terhadap pengalaman religius. Dengan keterbukaan Calvin yang demikian, doa mistik Karl Rahner dapat menjadi sebuah sarana bagi kalangan Reformed konservatif untuk menghadirkan aspek misteri dan kekaguman dalam iman.

Kata-kata Kunci: pascakebenaran, mistik, mistisisme, Calvin, Karl Rahner

\section{Pendahuluan}

Michael Horton mengakui bahwa teologi Calvin dianggap sebagai teologi yang kaku, dingin, dan rasionalistik. ${ }^{1}$ Hal ini karena teologi Calvin tidak dapat terlepas dari pengaruh era Renaisans. Pada zaman Renaisans, para sarjana kembali mempelajari literaturliteratur Yunani kuno yang sebelumnya telah lama ditinggalkan. Kembalinya para sarjana kepada literatur Yunani kuno turut berdampak menjadikan Sola Scriptura sebagai prinsip utama gerakan Reformasi. Kekristenan yang berakar pada Reformasi menjadi "a religion of the book." Seturut dengan hal ini, hal-hal yang bersifat takhayul dan mistis dari Abad Pertengahan juga mulai dihilangkan. Bryan Chapel mengatakan bahwa Reformasi menganggap segala hal yang berbau takhayul sebagai musuh dalam ibadahnya. ${ }^{3}$ Prinsip Sola Scriptura yang dimaksudkan untuk memusatkan kembali kebenaran kepada teks Alkitab kemudian malah menyebabkan perpecahan aliran dan denominasi karena adanya berbagai perbedaan penafsiran, misalnya atas makna baptisan dan perjamuan kudus ${ }^{4}$ Gerakan Reformasi menjadi suatu gerakan yang berpolemik pada intelektualitas dan hal-hal empiris, seperti yang William Bulman ungkapkan demikian, "the polemics and struggles

\footnotetext{
${ }^{1}$ Michael Horton, Calvin on the Christian Life: Glorifying and Enjoying God Forever (Wheaton, IL: Crossway, 2014), 45.

2 Kenneth R. Bartlett and Margaret McGlynn, The Renaissance and Reformation in Northern Europe (Toronto: University of Toronto Press, 2014), xvii.

3 Bryan Chapel, Christ-Centered Worship (Grand Rapids, MI: Baker Academic, 2009), 66.

4 J. I. Packer mengatakan ada enam hal penyebab perpecahan di kalangan Protestan karena perbedaan penafsiran teks, yakni: (1) kedaulatan Allah dan kekebasan manusia, (2) perjamuan kudus, (3) eklesiologi, (4) hubungan antara gereja dengan negara, (5) baptisan, dan (6) eskalotogi. J. I. Packer, "'Sola Scriptura' in History and Today," in God's Inerrant Word: An International Symposium on the Trustworthiness of Scripture, ed. John Warwick Montgomery (Minneapolis, MN: Bethany, 1974), 56.
} 
of the Reformation and its aftermath centered intellectual effort on scriptural scholarship and empirical observation." 5

Menulis dari sudut pandang Reformed, Howard L. Rice mengatakan bahwa banyak kalangan Protestan masih terikat dengan masa lalu dan menolak praktik keagamaan yang dahulu ditolak oleh para tokoh Reformasi, seperti misalnya doa keheningan dan berlutut. Padahal, konteks zaman kini telah berubah sehingga penolakan itu sesungguhnya bukan berdasarkan alasan yang alkitabiah. Mereka menolaknya karena hal-hal tersebut adalah praktik dari kalangan Katolik Roma. ${ }^{6}$ Selain itu, Rice juga mengakui bahwa kalangan Reformed takut berbicara mengenai pengalaman pribadi dan ada sebuah konotasi negatif terhadap hal tersebut. Banyak orang Kristen membentengi diri terhadap pengalaman akan Tuhan. Mereka membatasi diri hanya kepada apa yang kelima indera mereka dapat alami. ${ }^{7}$

Di kalangan Injili, Jonathan Parnell pernah secara terbuka mengkritik John Piper yang menyarankan praktik lectio divina. Menurut Parnell, lectio divina dan spiritualitas yang bersifat kontemplatif perlu ditolak karena menyerupai praktik mistik. ${ }^{8}$ Tim Challis juga menulis sebuah artikel di mana ia menunjukkan kekhawatiran atas pengaruh mistisisme terhadap gereja-gereja Injili di Amerika Serikat. Tulisnya, "Mysticism has wormed its way inside Evangelicalism so that the two have become integrated and almost inseparable. In an age of syncretism, we fail to spot the contradiction and opposition." "Arthur L. Johnson juga menulis sebuah buku yang mengkritik mistisisme. Bagi Johnson, mistisisme bertentangan dengan Alkitab, dan pengajaran mengenai deeper spiritual life adalah suatu pengajaran yang bermasalah karena berakar pada mistisisme Katolik. ${ }^{10}$ Johnson menambahkan bahwa mistisisme menolak akal budi sehingga dengan demikian maka tidak dapat dibantah pula dengan akal budi. Ia juga menuduh mistikus Kristen meniadakan perlunya pengorbanan Kristus di

5 William J. Bulman, "Introduction: Enlightenment for the Cultural Wars," in God in the Enlightenment, eds., William J. Bulman and Robert G. Ingram (New York: Oxford University Press, 2016), 16.

${ }^{6}$ Howard L. Rice, Reformed Spirituality (Louisville, KY: Westminster John Knox, 1991), 18.

${ }^{7}$ Ibid., 23-24.

8 Jonathan Parnell, “A System for Praying," Desiring God, January 1, 2012, https://www.desiringgod.org/articles/a-system-for-praying-in-2012.

9 Tim Challies, "The Boundaries of Evangelicalism," Challies, May 8, 2013. http://www.challies.com/articles/the-boundaries-of-evangelicalism.

10 Arthur L. Johnson, Faith Misguided: Exposing the Dangers of Mysticism (Chicago, IL: Moody Press, 1988), 11, 15. Makalah ini tidak membahas pandangan buku tersebut secara kritis, namun penulis berpendapat bahwa Johnson terlalu menyederhanakan mistisisme. Berbagai tudingannya terhadap mistisisme menunjukkan bahwa ia kurang mengerti mengenai sejarah, kekayaan, dan keberagaman aliran mistik. 
kayu salib. ${ }^{11}$ Bagi Johnson, satu-satunya solusi untuk menangkal mistisisme adalah kembali kepada akal budi (restoration of reason). ${ }^{12}$

R.C Sproul pernah mengeluhkan kenyataan bahwa banyak orang Kristen hanya mengumpulkan berbagai pengetahuan teologi namun hatinya dingin dan steril. ${ }^{13}$ Meski demikian, banyak buku baru yang diterbitkan hingga lima tahun terakhir baik dari kalangan Reformed dan Injili masih menawarkan logika dan rasionalitas iman kepada pembacanya. ${ }^{14}$ Padahal dengan datangnya era pascakebenaran, dominasi akal budi dalam melihat kebenaran akan semakin tersisihkan.

Melalui tulisan ini, penulis ingin berargumentasi bahwa karya Calvin seharusnya memberikan ruang bagi kalangan Reformed untuk bersikap terbuka terhadap pengalaman mistik. Hal ini menjadi penting karena di era pascakebenaran ini hal-hal yang bersifat emosional justru lebih mendapatkan tempatnya. ${ }^{15}$ Artikel ini juga menawarkan doa mistik Karl Rahner untuk membantu kalangan Reformed mengalami iman yang disertai dengan hadirnya unsur misteri dan kekaguman. Untuk itu, maka penulis pertamatama menjelaskan apa itu era pascakebenaran serta dampaknya terhadap dinamika iman masa kini. Selanjutnya, melalui sumber sekunder maupun primer, penulis akan menelaah berbagai aspek pengalaman religius dalam karya Calvin dengan tujuan untuk memperlihatkan bahwa karya Calvin tidaklah kaku dan dingin seperti yang diasumsikan pada umumnya. Penulis menyadari bahwa tradisi Calvinisme yang dipegang oleh kalangan Reformed saat ini memang tidak dapat disamakan begitu saja dengan ajaran Calvin. ${ }^{16}$ Tetapi karena ajaran Calvinisme yang dipegang oleh kalangan Reformed saat ini berakar pada karya Calvin, maka karya Calvin menjadi perlu dibicarakan agar gagasan mula-mula Calvin mengenai kehidupan Kristen yang sesungguhnya dapat ditelusuri kembali. Selain itu, menelaah kembali karya Calvin juga diharapkan

\footnotetext{
11 Ibid., 32, 35 .

12 Ibid., 69.

${ }^{13}$ R. C. Sproul, The Soul's Quest for God: Satisfying the Hunger for Spiritual Communion with God (Phillipsburg, NJ: P\&R Publishing, 2003), 5.

${ }^{14}$ Di antaranya adalah Stephen T. Davies, Rational Faith: A Philosopher's Defense of Christianity (Oxford: InterVarsity Press, 2016). Pendekatan dalam buku Davies adalah dari sisi filsafat; lalu ada pula Patrick Ford, Faith Isn't Blind: Logical Arguments from Science, History, and Philosophy that God Really Exists (Bloomington, IN: Westbow, 2016) yang menekankan argumen-argumen dari filsafat, khususnya era skolastik; Timothy Keller, Making Sense of God: Finding God in the Modern World (New York: Penguin Books, 2018), yang mana bab tiga dari buku Keller sangat menekankan keunggulan rasionalitas dalam beriman.

15 Era pascakebenaran merujuk kepada era di mana emosi dan keyakinan individu lebih berperan dalam membentuk opini publik daripada fakta-fakta objektif. Hal ini akan dibahas secara lebih rinci dalam bagian selanjutnya.

${ }^{16}$ Christiaan De Jonge, Apa Itu Calvinisme (Jakarta: BPK Gunung Mulia, 2008), 2.
} 
dapat membuka ruang diskusi dengan kalangan Reformed terkait aspek mistik dari iman.

\section{Pudarnya Dominasi Akal Budi di Era Pascakebenaran}

Apakah itu pascakebenaran? Kamus Oxford menobatkan kata 'pascakebenaran' (post-truth) sebagai word of the year pada tahun 2016 dan mendefinisikannya sebagai suatu kondisi yang di dalamnya emosi dan keyakinan individu lebih berperan dalam membentuk opini publik daripada fakta-fakta objektif. ${ }^{17}$ Ketika Donald Trump berkampanye di Amerika Serikat pada tahun 2016, pendukungnya tidak lagi peduli mengecek bukti dan fakta atas berbagai pernyataan yang Trump lontarkan kepada lawannya. Pendukungnya lebih melihat kebenaran pada tataran emosi dan afektif. Telah terjadi pergeseran dalam melihat kebenaran di mana rasionalitas mulai terpinggirkan dan emosi kini berperan sebagai faktor utama. ${ }^{18}$ Pemilihan presiden Amerika Serikat di bulan November 2020 juga semakin menegaskan bahwa masyarakat Amerika saat ini semakin mengarah kepada masyarakat pascakebenaran. ${ }^{19}$ Hal ini ditunjukkan dari keberhasilan media sayap kanan di Amerika Serikat memengaruhi pendukung Trump sehingga mereka percaya bahwa ia sesungguhnya adalah pemenang pemilu 2020. Era pascakebenaran juga telah merambah ke Indonesia. Franz Magnis-Suseno tanpa ragu menegaskan bahwa, "We here in Indonesia know what post-truth is," dan ia merujuk kepada kasus kekalahan dan penahanan Basuki Tjahaja Purnama sebagai salah satu dampaknya. ${ }^{20}$

Lantas, apa kaitan pascakebenaran dengan spiritualitas dan bagaimanakah seseorang dari tradisi Reformed dapat menyikapinya? Dalam konteks spiritualitas Kristen, Brett McCracken mengatakan bahwa banyaknya informasi yang beredar di era ini berdampak pada masalah mental dan spiritual. ${ }^{21}$ Banyak

${ }_{17}$ Untuk definisi resmi pascakebenaran, lihat kamus resmi Oxford di https://languages.oup.com/word-of-the-year/2016/. Lihat juga Michael A. Peters, "Education in a Post-Truth World," Educational Philosophy and Theory, Vol. 49, No. $\quad 6 \quad$ (2017): 563. https://www.tandfonline.com/doi/full/10.1080/00131857.2016.1264114.

18 Megan Boler and Elizabeth Davis, "The Affective Politics of the 'Post-Truth' Era: Feeling Rules and Networked Subjectivity," Emotion, Space and Society, Vol. 27 (2018): 75.

${ }^{19}$ Peter Grier and Story Hinckley, "Two Ways to Read the Story," The Christian Science Monitor, November 19, 2020, https://www.csmonitor.com/USA/Politics/2020/1119/Post-truth-politics-

As-Trump-pushes-fraud-partisans-pick-their-own-reality.

${ }^{20}$ Franz Magnis-Suseno, "Philosophy, A Challenge to Post-Truth, also in Indonesia," Jurnal Filsafat, Vol. 30, No. 1 (2020): 16. https://jurnal.ugm.ac.id/wisdom/article/view/53671/27166.

${ }^{21}$ Brett McCracken, The Wisdom Pyramid: Feeding Your Soul in a Post-Truth World (Wheaton, IL: Crossway, 2021), introduction, Kindle. 
orang menjadi gelisah, stres dan jiwa-jiwa menjadi lelah. Orangorang menjadi buta akan apa yang esensial bagi dirinya dan mengalami kekosongan spiritual. Banyak orang menjadi tidak bahagia. Sulit bagi seseorang untuk dapat berdiam diri. Salah satu masalah yang dihadapi orang banyak masa kini adalah "more distraction; less stillness." 22 Berbeda dari McCracken yang mengajak pembacanya untuk tidak terjebak di dalam paradigma pascakebenaran, Douglas dan Rhonda H. Jacobsen justru mengatakan bahwa era ini perlu dihadapi melalui kesadaran bahwa aspek-aspek iman telah mengalami banyak pergeseran. Selama ini pendekatan agama seringkali terpusat pada pemikiran, logika, dan riset semata. Beriman di era ini membuat seseorang perlu melihat hal-hal lain selain rasionalitas. Rasionalitas memang diperlukan dalam beriman dan orang-orang Kristen pun perlu turut berperan serta di dalam pengembangan ilmu pengetahuan. ${ }^{23}$ Namun, Douglas dan Rhonda H. Jacobsen berpendapat bahwa ada empat hal lain yang perlu diperhatikan terhadap aspek iman di era pascakebenaran. Pertama, perlu adanya proklamasi atau pengakuan atas iman. Kedua, diperlukan adanya kasih sayang kepada sesama. Ketiga, diperlukan terjadinya transformasi diri secara pribadi. Terakhir, perlu hadirnya unsur mystery/wonder di dalam iman. Misteri dan kekaguman kini bukanlah sesuatu yang perlu dihindari, melainkan sesuatu yang perlu disambut, dihargai dan dirayakan. ${ }^{24}$

\section{Tinjauan terhadap Pengalaman Mistis}

Apa itu pengalaman mistis? Pertama, perlu diterangkan perihal yang bukan dimaksud dengan pengalaman mistis. Pengalaman mistis di dalam tulisan ini bukanlah pengalaman mengenai seseorang yang diangkat ke surga atau neraka. Pengalaman ini juga tidak terpaku kepada pengalaman visual atau pendengaran akan suara Tuhan, meskipun mungkin terjadi. Pengalaman ini juga bukanlah sebuah pengalaman okultisme dengan kuasa-kuasa lain yang bukan berasal dari Tuhan. Terakhir, pengalaman mistis bukanlah pengalaman yang dihasilkan dari peningkatan kapasitas tubuh manusia secara alami seperti yang dicapai oleh orang-orang yang bermeditasi. Pengalaman mistis yang dimaksud di sini adalah sebuah pengalaman spiritual yang personal dan nyata namun tidak dapat dibuktikan secara empiris.

Susan L. DeHoff, yang menulis mengenai teologi mistik Jean Gerson (1363-1429), mengatakan bahwa bahwa teologi mistik

22 Ibid.

${ }^{23}$ Douglas Jacobsen and Rhonda H. Jacobsen, "Faith and Learning in a Post-Truth World," Journal of College and Character, Vol. 19, No. 2 (2018): 97. https://www.tandfonline.com/doi/full/10.1080/2194587X.2018.1445645.

${ }^{24}$ Sebagai rangkuman, lima aspek iman di era pascakebenaran yang perlu diperhatikan ini adalah proclamation, rationality, compassion, transformation, serta mystery/wonder: Ibid., 95. 
Gerson memiliki "an experiential knowledge of God." 25 Dalam pengalaman tersebut, Tuhan hadir dalam kesadaran diri seseorang. ${ }^{26}$ Sedangkan Kirk E. Farnsworth merumuskan pengalaman mistis sebagai "a process of responding to an objective God outside of oneself with a feeling concerning Him and what He has communicated, not just a feeling of one's inner self." ${ }^{27}$ Dalam meneliti karya Jonathan Edwards, Farnsworth berkesimpulan bahwa "true religious experience is based on the subjective encounter of the objective reality of God." ${ }^{28}$ Pengalaman mistis adalah sebuah respons dari seseorang atas perjumpaannya dengan Allah yang dialaminya secara subjektif. Pengalaman tersebut merupakan sebuah respons atas pertemuan seseorang dengan Tuhan yang termanifestasi di dalam batinnya secara subjektif dalam suatu momen tertentu. ${ }^{29}$ William James, seorang psikolog dan pengamat mistisisme pada awal abad ke-20, mengidentifikasikan pengalaman tersebut dengan beberapa ciri khas. Pertama, adanya ineffability yang berarti pengalaman tersebut sulit dideskripsikan atau dijelaskan oleh orang-orang yang mengalaminya. Kedua, adanya noetic quality yang berarti pengalaman tersebut memberikan suatu pengetahuan atau kesadaran baru. Ketiga, adanya transiency, pengalaman tersebut bersifat sementara, hanya terjadi sesaat. Terakhir, passivity, yakni mereka yang mengalaminya bersifat pasif, seakan-akan digenggam oleh sebuah kekuatan yang besar. ${ }^{30}$

\section{Tinjauan Pengalaman Mistis dalam Teologi Calvin}

Teologi Calvin sering diasosiasikan sebagai teologi yang mengedepankan rasionalitas. Morton Kelsey mengakui bahwa, berada di dalam teologi Reformed, ia hanya mengenal sisi intelektual dari teologi Calvin saja. ${ }^{31}$ Howard L. Rice juga mengakui bahwa Yohanes Calvin sering dipandang sebagai seorang tokoh yang mengedepankan intelektualitas. ${ }^{32}$ Karena itu kalangan Reformed sering bersikap curiga terhadap hal-hal yang menyangkut pengalaman spiritual; bahkan kata "spiritual" itu sendiri cukup

25 Susan L. DeHoff, Psychosis or Mystical Religious Experience? A New Paradigm Grounded in Psychology and Reformed Theology (Boston, MA: Palgrave Macmillan, 2018), 7.

${ }^{26}$ Ibid.

${ }^{27}$ Kirk E. Farnsworth, Wholehearted Integration: Harmonizing Psychology and Christianity Through Word and Deed (Grand Rapids, MI: Baker Book House, 1985), 98.

28 Ibid., 69.

29 Batin adalah sesuatu yang terdapat di dalam hati; sesuatu yang menyangkut jiwa (perasaan hati dan sebagainya). https://kbbi.web.id/batin.

${ }^{30}$ William James, The Varieties of Religious Experience: A Study in Human Nature, Centenary Edition (New York: Routledge, 2002), 295.

${ }^{31}$ Morton Kelsey, foreword to Rice, Reformed Spirituality, 1.

32 Rice, Reformed Spirituality, 11. 
membuat kalangan Reformed tidak nyaman. ${ }^{33}$ Pengalaman spiritual seringkali dianggap sebagai praktik Abad Pertengahan yang dikutuk oleh kalangan Reformed. Hal ini dikarenakan Calvin menekankan anugerah Allah sehingga praktik formasi spiritual di dalam sejarah kekristenan masa lampau, yang biasanya digambarkan lewat adanya tangga untuk menggapai Tuhan (a ladder to God), dicurigai sebagai sebuah upaya manusia untuk membangun sebuah jembatan menuju kepada Tuhan. ${ }^{34}$ Akibat ketakutan ini, maka kaum Reformed cenderung mengabaikan kehidupan batin (inner life) mereka. "The inner life has been neglected to the point that many Reformed Christians are obedient and faithful out of a sense of loyalty and duty, but without much joy and enthusiasm," ujar Rice ${ }^{35}$ Mereka yang menghidupi iman dengan cara demikian dapat dipandang bersalah karena telah memisahkan iman sebagai perumusan doktrin dengan iman sebagai sebuah respons yang emosional atas cinta kasih Tuhan. "The Christian life has been reduced to assent to the proper doctrines," tegas Rice. ${ }^{36}$ Hidup yang saleh (piety) bagi kaum Protestan sering terdengar sebagai disiplin yang kaku karena mereka takut menemukan sebuah sukacita sehingga lebih memilih untuk bersikap dingin dan mengikuti aturan. ${ }^{37}$

Di tengah kelangkaan kaum Reformed membahas mengenai pengalaman mistis, di tahun 2018 terbit sebuah buku karya Susan L. DeHoff yang membahas mystical religious experience dari sudut pandang Calvin. Buku ini berupaya menyadarkan kembali mengenai pentingnya elemen-elemen mistik dalam tulisan Calvin yang selama ini terabaikan. DeHoff menyimpulkan bahwa religiositas Calvin sesungguhnya mencakup unsur pengalaman yang berkaitan dengan Tuhan. Hoff menuliskan demikian, "Religious, therefore, can be used adjectivally to describe anything associated with that toward which one feels reverent, including experiences associated with God." ${ }^{38}$ Bagi DeHoff, doktrin penyatuan mistis Calvin (mystical union) sesungguhnya memuat unsur pengalaman karena tujuan Calvin adalah untuk mereformasi ajaran gereja agar "kepala" dapat bertemu dengan "hati" di dalam iman. ${ }^{39}$ Unsur pengalaman ini bukanlah sesuatu yang natural seperti layaknya pengalaman psikologis yang transenden ketika berjalan di alam 33 Ibid., 45.
34 Ibid., 50.
35 Ibid., 53.
36 Ibid., 58.
37 Ibid., 46.
38 DeHoff, Psychosis or Mystical Religious Experience? 8.
${ }^{39}$ Ibid., 28. Untuk doktrin mystical union dari Calvin, lihat John Calvin,
Institutes of the Christian Religion, trans., Henry Beveridge (Grand Rapids, MI: WM. B. Eerdmans, 1989), III.xi.10. 
terbuka. Untuk menggolongkannya sebagai pengalaman religius, pengalaman tersebut harus melibatkan Allah Tritunggal. ${ }^{40}$

DeHoff lebih jauh berpendapat bahwa teologi penyatuan mistis Calvin sebenarnya tidaklah lepas dari pengaruh tulisan Bernardus dari Clairvaux. ${ }^{41}$ Penekanan Calvin terhadap pentingnya relasi personal antara orang percaya dengan Tuhan melalui penyatuan dengan Kristus sesungguhnya mengacu kepada tulisan Bernardus. ${ }^{42}$ Selain DeHoff, Dennis E. Tamburello juga pernah meneliti kedua tokoh tersebut secara saksama. ${ }^{43}$ Tamburello menunjukkan adanya kesinambungan teologi penyatuan mistis Bernardus dengan Calvin. ${ }^{44}$ Beberapa kesinambungan teologi tersebut adalah sebagai berikut: Pertama, penyatuan (union) adalah anugerah dari Tuhan, bukan karya manusia. Kedua, natur dari penyatuan adalah secara spiritual, bukan percampuran esensi. Ketiga, penyatuan adalah penyatuan kehendak dengan komponen kognitif iman. Keempat, penyatuan melibatkan kasih yang aktif yang mengarah kepada Tuhan dan sesama. Kelima, penyatuan memberikan pengalaman bersama Tuhan (experential knowledge of God). Keenam, penyatuan mengandung unsur trinitarian. Ketujuh, penyatuan terjadi dalam konteks bergereja dan sakramen. Kedelapan, penyatuan akan terjadi sepenuhnya pada kebangkitan nanti. Dan kesembilan, penyatuan menggunakan gambaran pernikahan spiritual. Dengan demikian, dapatlah disimpulkan bahwa Calvin sebenarnya tidaklah anti dengan hal mistik. Michael Horton menyebutkan bahwa tulisan mistik Bernardus justru memengaruhi Calvin ${ }^{45}$ Horton secara terbuka mengakui bahwa teologi penyatuan mistis Calvin berutang kepada Bernardus. ${ }^{46}$ Bagi DeHoff, adanya unsur pengalaman dalam teologi penyatuan mistis Calvin menyiratkan bahwa pengalaman tidak boleh dipisahkan dari intelektualitas. "One more point needs to be made about the importance of mystical union, and that is that Calvin did not view this experience as divorced from the intellectual side of theology," tegasnya. ${ }^{47}$ Dengan senada, Horton juga berpendapat bahwa bagi

${ }^{40}$ DeHoff, Psychosis or Mystical Religious Experience? 12.

${ }^{41}$ Ibid., 33.

42 Ibid., 29, 42.

${ }^{43}$ Untuk studi pengaruh karya mistik Bernardus dari Clairvaux terhadap teologi Calvin, lihat Dennis E. Tamburello, Union with Christ: John Calvin and Mysticism of St. Bernard (Louisville, KY: Westminster John Knox, 1994).

44 Clive S. Chin, seorang profesor dari Singapore Bible College, merangkum hasil pengamatan Dennis E. Tamburello yang membandingkan karya Bernadus dari Clairvaux dengan Calvin. Lihat Clive S. Chin, "Calvin, Mystical Union, and Spirituality," Torch Trinity Journal, Vol. 6 (2003): 186. www.ttgst.ac.kr/upload/ttgst resources13/20123-164.pdf.

45 Calvin secara total mengutip tulisan mistik dari Bernardus secara langsung sebanyak 29 kali. Horton, Calvin on Christian Life, 93.

46 Ibid., 93.

${ }^{47}$ DeHoff, Psychosis or Mystical Religious Experience? 40. 
Calvin "knowing God is inseparable from experiencing God." 48 Tidak hanya Calvin terbuka terhadap pengalaman religius, Bernard McGinn menyatakan bahwa Calvin sendiri pernah mengalaminya ${ }^{49}$ Bersama McGinn, DeHoff mengemukakan bahwa pertobatan Calvin yang tertuang dalam tafsiran atas Kitab Mazmur sesungguhnya mengandung pengalaman religius yang sangat personal. Calvin menuliskannya demikian, "God by a sudden conversion subdued and brought my mind to a teachable frame, which was more hardened in such matters than might have been expected from one at my early period of life." 50 Dan Calvin melanjutkan, "I was immediately inflamed with so intense a desire to make progress therein, that although I did not altogether leave off other studies, I yet pursued them with less ardor." 51

Selain dipengaruhi karya mistik Bernardus, Calvin juga dipengaruhi oleh gerakan mistik Jerman Brethren of Common Life. Gerakan mereka yang bernama devotio moderna (modern devotion) tidak memandang kehidupan spiritualitas Kristen dengan cara menyendiri di dalam biara melainkan memilih untuk hidup di tengah-tengah kesibukan perkotaan. Melalui pengaruh spiritualitas ini, Calvin memandang bahwa spiritualitas Kristen tidak dapat dibatasi dalam biara; spiritualitas seharusnya berjalan dalam kehidupan sehari-hari. ${ }^{52}$

Akhir-akhir ini, penelitian juga menunjukkan bahwa tulisan Calvin yang berjudul Psychopannychia memiliki unsur naiknya jiwa (ascent of the soul) secara progresif kepada Tuhan seperti layaknya tulisan-tulisan kaum mistik di era sebelumnya. ${ }^{53}$ Dengan demikian, maka asumsi terhadap Calvin sebagai seorang tokoh yang hanya mengedepankan intelektualitas perlu dipertimbangkan kembali. William Bouswma juga menunjukkan bahwa dari abad ke-16 hingga ke-20, teologi Calvin seringkali hanya difokuskan pada prinsip-prinsip teologi yang dingin, kaku, khususnya pada pandangan predestinasinya sehingga aspek pengalaman iman diabaikan. Bouswma menilai bahwa tampaknya ada dua sosok Calvin yang berbeda yang dapat dikenali. Sosok yang satu adalah sosok Calvin yang cenderung teoretis sedangkan yang lainnya

${ }^{48}$ Horton, Calvin on Christian Life, 45.

49 Bernard McGinn, "Mysticism," in The Oxford Encyclopedia of the Reformation, Vol. 3, ed., Hans Hillerbrand (New York: Oxford University Press, 1996), 122, quoted in Chin, "Calvin, Mystical Union, and Spirituality," 184.

${ }^{50}$ John Calvin, Commentary on the Book of Psalms, Vol. 1, trans., James Anderson (Grand Rapids, MI: Eerdmans, t.t.), 25, https://www.ccel.org/ccel/calvin/calcom08.html.

51 Ibid., 25.

52 Horton berpendapat bahwa praktik spiritual Calvin secara tidak langsung dipengaruhi oleh kaum Brethren ini. Lihat Horton, Calvin on Christian Life, 40.

53 Untuk buku yang dimaksud, lihat Julie Canlis, Calvin's Ladder: A Spiritual Theology of Ascent and Ascension (Grand Rapids, MI: Eerdmans, 2010). 
adalah sosok yang cenderung merayakan paradoks dan misteri, yang melihat bahwa pengalaman dan praktik spiritual lebih penting daripada sekadar teori. ${ }^{54}$

\section{Telaah atas Karya Calvin}

Dalam Institutes dan tafsiran atas Kitab Mazmur, Calvin sebenarnya menekankan pengalaman pribadi bersama Tuhan meskipun tidak secara eksplisit ataupun dominan. Dalam bab pertama Institutes, Calvin mengajak pembacanya merenung dan merefleksikan Tuhan karena manusia seringkali terlalu percaya diri atas kualitas spiritual dalam dirinya. ${ }^{55}$ Bagi Calvin, berbagai pengetahuan akan Tuhan yang dipelajari akan menjadi sia-sia dan menjadi spekulasi belaka apabila hanya berhenti di pikiran saja namun tidak sampai dan berakar di hati. Calvin menulis bahwa "the knowledge of God which we are invited to cultivate is not that which, resting satisfied with empty speculation, only flutters in the brain, but a knowledge which will prove substantial and fruitful wherever it is duly perceived, and rooted in the heart." 56

Meskipun manusia sangat tertarik belajar tentang Tuhan, Calvin mengatakan bahwa esensi diri Tuhan adalah untuk disembah dan dipuja daripada sebagai objek penyelidikan. ${ }^{57}$ Apabila manusia hanya tertarik untuk menyelidiki Tuhan, maka sebenarnya ia hanya berdelusi dalam spekulasi-spekulasi dingin (frigid speculation) semata. ${ }^{58}$ Ketika berbicara mengenai karakter keilahian Tuhan, Calvin menegaskan bahwa manusia perlu merenungkan Tuhan yang mendekat kepadanya dan dengan cara-Nya Ia mengomunikasikan diri-Nya kepada kita. ${ }^{59}$ Calvin menekankan perlunya Tuhan untuk hadir dalam diri seseorang agar ia mempunyai pengalaman kegentaran dan kekaguman akan Tuhan yang membuatnya ingin menyembah-Nya. Bagi Calvin, pikiran manusia mengenai Tuhan cenderung terbawa pada hal-hal yang sifatnya spekulatif padahal hal-hal tersebut tidak memberikan keuntungan sama sekali. Hal-hal demikian membuat manusia mengabaikan manifestasi Tuhan dan gagal merefleksikan Dia yang sebenarnya hadir di depan mata. Calvin mengingatkan bahwa anugerah kasih Tuhan yang Paulus gambarkan sebagai betapa lebar dan panjang dan tinggi dan dalamnya itu perlu termanifestasikan di dalam diri manusia yang berada dalam Kristus. ${ }^{60}$

54 William Bouwsma, John Calvin (New York: Oxford University Press, 1988), 231. Lihat juga DeHoff, Psychosis or Mystical Religious Experience? 31.

55 Calvin, Institutes of the Christian Religion, I.i.2.

56 Ibid., I.v.9.

57 Ibid., I.ii.1.

${ }^{58}$ Ibid., I.ii.2.

${ }^{59}$ Ibid., I.x.2.

${ }^{60}$ John Calvin, Psalms 93-150, Vol. 4 of Calvin's Commentaries on the Book of Psalms, trans., James Anderson (Grand Rapids, MI: Baker Books, 1989), 133. 
Calvin juga menegaskan bahwa apa yang manusia percayai dan ekspresikan dari mulutnya haruslah berkorespondensi dengan perasaan dalam hatinya. Ia menulis bahwa "the external professions of the lips correspond with the internal feelings of the heart." ${ }_{1}$ Dengan demikian, iman tidak boleh terlepas dari hati "Faith cannot remain inoperative in the heart, but that it must, of necessity, manifest itself," tegasnya. ${ }^{62}$ Bagi Calvin, perasaan adalah salah satu anugerah dari Tuhan yang penting untuk hadir dalam diri kita agar memampukan kita untuk hidup benar. Tulisnya, ${ }^{63}$

The better to manifest this, we must lay it down as a first principle, that seeing, hearing, walking, and feeling, are God's precious gifts; that our understandings and will, with which we are furnished, are a still more valuable gift; and, after all, there is no look of the eyes, no motion of the senses, no thought of the mind, unmingled with vice and depravity.

Calvin juga menekankan pentingnya sebuah pengalaman pribadi ketika berbicara mengenai pemeliharaan Allah. Baginya, pemeliharaan Allah seharusnya membawa sukacita yang diibaratkan seperti ledakan spontan dari dalam hati orang percaya. "For the joy which they experience in this exercise is a pledge that their thus observing these things was the spontaneous effusion of their hearts," tulisnya. ${ }^{64}$ Apa yang Calvin tuliskan, yakni pengalaman pribadi seseorang yang dapat menjadi "ledakan spontan," sesungguhnya selaras dengan karakteristik pengalaman mistis yang diidentifikasikan oleh William James, yakni transiency-sebuah pengalaman puncak yang sifatnya sementara. Calvin memang tidak mengklaim dirinya sebagai seorang mistikus, namun penekanan atas pentingnya pengalaman tersebut membuatnya dekat dengan salah satu ciri khas pengalaman mistis yang dideskripsikan oleh James.

Calvin juga melihat bahwa pengalaman sukacita dari Tuhan adalah sebuah pengalaman yang sangat menguntungkan bagi orang percaya. Ia mengingatkan bahwa jangan sampai umat Kristen justru mengabaikan kebaikan dan kuasa Tuhan yang secara ekstrem dapat mereka alami. "Let us not be unmindful of his goodness and power, which we experienced in our extremity," tegasnya. ${ }^{65}$

Tulisan Calvin mengenai memikul salib juga mempunyai unsur pengalaman religius. Manfaat memikul salib Kristus adalah umat Kristen ssenantiasa merendahkan hati mereka, mengandalkan pertolongan Tuhan, serta mengalami kehadiran Tuhan ("to give us

\footnotetext{
${ }^{61}$ Ibid., 366.

62 Ibid.

${ }^{63}$ Ibid., 428. Cetak miring ditambahkan.

${ }^{64}$ Ibid., 265. Cetak miring ditambahkan.

65 Ibid., 380.
} 
experience of God's presence"). ${ }^{66}$ Calvin juga mengatakan bahwa salah satu modal utama untuk hidup dengan rendah hati dan lepas dari kedagingan adalah dengan mengalami kehadiran kuasa ilahi ("experience the presence of the divine power"). ${ }^{67}$

Melihat berbagai penekanan unsur pengalaman yang ada, bagi Calvin sebuah kehidupan Kristen bukanlah sebuah kehidupan yang kaku, dingin dan mengabaikan pengalaman pribadi. Calvin mengingatkan relasi doktrin dengan kehidupan Kristen sebagai demikian, "Doctrine is not an affair of the tongue, but of the life; is not apprehended by the intellect and memory merely, like other branches of learning; but is received only when it possesses the whole soul and finds its seat and habitation in the inmost recesses of the heart." ${ }^{68}$

Calvin juga berharap agar perenungan akan misteri ilahi dapat hadir di dalam iman. Ia menuliskannya demikian, "May the Lord grant, that we may engage in contemplating the mysteries of his heavenly wisdom with really increasing devotion, to his glory and to our edification. Amen. ${ }^{\prime 99}$ Meskipun perenungan atas misteri ilahi tidaklah dominan di dalam karya Calvin, namun jelas bahwa Calvin tidak menampik bahwa hal ini adalah sesuatu yang diperlukan di dalam kehidupan orang beriman.

Meski karya Calvin memuat unsur pengalaman religius dan mendorong kontemplasi akan misteri, prioritas Calvin adalah mewujudkan sebuah hidup yang saleh (piety). Beberapa tulisan Calvin berikut ini menunjukkan bahwa teologi Calvin berpusat pada kesalehan. Pertama, dalam merangkum seluruh tujuan hidup seorang Kristen, Calvin mengatakan bahwa Tuhan hanya meminta kesalehan dan tidak lebih daripada itu. Hidup saleh merupakan pencapaian yang terakhir. Dengan demikian, kita perlu melatih tubuh kita sedemikian rupa agar tidak gagal mempraktikkan kesalehan. ${ }^{70}$ Kedua, dalam tafsiran 1 Timotius, Calvin berpendapat bahwa kebahagiaan yang sejati terletak pada hidup saleh. "Thus, true happiness consists in piety; and this sufficiency may be regarded as an increase of gain," tulisnya. ${ }^{71}$ Ketiga, dalam pendahuluan Institutes dari Calvin, John T. McNeill menyimpulkan bahwa Calvin melihat buku teologinya sebagai a

${ }^{66}$ Calvin, Institutes of the Christian Religion, III.viii.

${ }^{67}$ Ibid., III.viii. 2.

${ }^{68}$ Ibid., III.viii.4.

${ }^{69}$ John Calvin, Hosea, Vol. 1 of Commeantaries on the Twelve Minor Prophets, trans., John Owen (Grand Rapids, MI: Eerdsmans, t.t.), 19. https://ccel.org/ccel/calvin/calcom26/calcom26.vii.html; Horton, Calvin on Christian Life, 42.

${ }^{70}$ John Calvin, The Epistles to Timothy, Titus and Philemon, Vol. 21 of Calvin's Commentaries, trans., William Pringle (Grand Rapids, MI: Baker Books, 1989), 110.

${ }^{71}$ Ibid., 158. 
summa pietatis. Rahasia dari kekuatan teologinya adalah pada cara hidup saleh. Kesalehan merupakan produk akhir dari teologinya. ${ }^{72}$

Apakah sesungguhnya yang dimaksud Calvin dengan kesalehan? Kyung Sik Joo mengungkapkan bahwa kesalehan Calvin selama ini terlalu dititikberatkan pada teologi, sistematika, spekulasi, doktrin, dan konsep yang terpisah dari konteks hidup pribadi Calvin. ${ }^{73}$ Kyung berusaha meneliti kehidupan pribadi Calvin untuk mengerti secara lebih personal apa yang Calvin maksud dengan "kesalehan." Kesimpulannya, "kesalehan" bagi Calvin dapat dipandang sebagai ${ }^{74}$

our recognition of God as our Father and it is our reverence and love for our Father that leads to a wellestablished relationship with Him. Piety is particularly abandoning our sinful and self-centred nature as well as our ignorance and arrogance to instead be regenerated with a God-centred faith that we adhere to.

Dengan demikian, meski unsur pengalaman dalam kehidupan saleh Calvin mencakup adanya perasaan takut, hormat, serta kasih (reverence and love) kepada Bapa, namun belum secara intensional bertujuan membangkitkan hadirnya unsur misteri dan kekaguman iman, baik seperti yang Calvin sendiri harapkan maupun yang Douglas dan Rhonda H. Jacobsen ungkapkan. Horton sendiri mengakui bahwa banyak orang menggemari teologi dan eksegesis Calvin namun ketika mencari panduan spiritualitas, mereka mencarinya di tempat lain. ${ }^{75}$ Rice juga mengatakan bahwa, "there are many people for whom ordinary religious practices are not sufficient. They seek a deeper experiential relationship with God and faith that is grounded in "firsthand knowing." "'76 Dengan menyadari perlunya semangat transformasi iman yang diikuti oleh semangat keterbukaan seperti yang Douglas dan Rhonda $\mathrm{H}$. Jacobsen ungkapkan, maka kalangan Reformed berkesempatan menilik tokoh spiritual di luar tradisi Calvin guna menghadirkan aspek iman yang dibutuhkan tersebut.

${ }^{72}$ John T. McNeill, introduction to Institutes of the Christian Religion by John Calvin, ed., trans., Ford Lewis Battles (Philadelphia, PA: Westminster Press, 1960), iii.

${ }^{73}$ Kyung Sik Joo, "The Nature and Characteristics of Calvin's Piety," Journal of Theological Reflections, Vol. 2 (2016): 186-187. http://scd.edu.au/wpcontent/uploads/sites/2/2017/04/06-주경식155-190.pdf.

74 Ibid., 175.

75 Horton, Calvin on Christian Life, 13.

${ }^{76}$ Rice, Reformed Spirituality, 8. 


\section{Kontribusi Karl Rahner}

Untuk belajar dari tokoh lain guna menghadirkan aspek misteri dan kekaguman dalam iman, maka Karl Rahner dapat memberikan kontribusi. Ada dua alasan mengapa Karl Rahner, seorang teolog Katolik abad ke-20, mampu memberikan kontribusi terhadap pengalaman iman bagi kalangan Reformed. Pertama, James W. Sire dan Camden Bucey menilai bahwa pandangan Rahner mempunyai sebuah titik temu dengan Calvin. ${ }^{77}$ Kedua, dari perspektif Douglas dan Rhonda H. Jacobsen, karya Rahner menampilkan hasrat yang menghantarkan aspek misteri ke dalam $\operatorname{iman}^{78}$

Bagi Rahner, manusia senantiasa memiliki hubungan dengan Allah dan hubungan dengan Allah tersebut adalah sebuah prinsip yang hakiki di dalam kesadarannya serta di dalam aktivitasnya mengetahui segala sesuatu. Rahner menyebut hal ini sebagai pre-apprehension of God atau dalam bahasa Jerman disebut sebagai Vorgriff. Ia menguraikannya demikian, "man is a transcendent being insofar as all of his knowledge and all of his conscious activity is grounded in a pre-apprehension (Vorgriff) of 'being' as such, in an ever-present knowledge of the infinity of reality." ${ }^{\text {"79 }}$ Setiap orang pada dasarnya mengalami sesuatu yang melampaui dirinya, mengalami Tuhan meskipun secara temaram. Tuhan dialami setiap orang secara samar-samar, secara tersembunyi dan tidak disadari. ${ }^{80}$ Pengalaman ini disebut juga Rahner sebagai pengalaman unthematic. ${ }^{81}$ Kesadaran akan Tuhan ini tidak eksplisit namun hadir di dalam cakrawala kesadaran (borizon of consciousness) yang tidak disadari oleh manusia. ${ }^{82}$ Sire menilai bahwa apa yang Rahner sebut sebagai pre-apprehension of God ini memiliki kesamaan dengan sensus divinitatis dari Calvin. ${ }^{83}$ Camden Bucey juga berpendapat demikian. Ia menyatakan bahwa epistemologi Rahner mempunyai persinggungan dengan sensus divinitatis di dalam teologi Reformed yang ia tuliskan sebagai berikut, "Whereas

${ }^{77}$ James W. Sire, Echoes of a Voice: We are not Silent (Eugene, OR: Wipf and Stock, 2014), 55.

78 Tujuan Rahner adalah untuk mengajak pembacanya melihat Tuhan tidak sebagai sebuah sosok yang two-dimensional, melainkan Tuhan sebagai the utter transcendence of Mystery. Mary Steinmetz, "Thoughts on the Experience of God in the Theology of Karl Rahner: Gifts and Implications," Lumen et Vita, Vol. 2, No. 1 (2012):

\section{1.}

https://ejournals.bc.edu/index.php/lumenetvita/article/view/1900.

${ }^{79}$ Karl Rahner, Foundations of Christian Faith: An Introduction to the Idea of Christianity, trans., William V. Dych (New York: Crossroad, 1978), 33.

${ }^{80}$ Ibid., 33-35.

${ }^{81}$ Ibid., 20-21.

82 Steinmetz, "Thoughts on the Experience of God," 1-2; lihat juga Harvey D. Egan, "The Mystical Theology of Karl Rahner," The Way, Vol. 52, No. 2 (2013): 43. https://www.theway.org.uk/back/522egan.pdf.

83 Sire, Echoes of a Voice, 55. 
Rahner develops the supernatural existential and the Vorgriff auf esse ["pre-apprehension of being"], Reformed theologians speak of the sensus divinitatus." 84 Bucey mengatakan bahwa, "Formally, Rahner has much in common with Reformed theologians on these matters." 85 Ia menyayangkan kalangan Reformed yang belum banyak memberikan perhatian atas hal ini, ${ }^{86}$

Fewer still have given Rahner much attention from within the Reformed tradition. This is regrettable not only because of Rahner's significance, but also because his theological themes overlap significantly with present day Reformed discussions, including the nature of revelation, the means and scope of glorification, the epistemological role of the sensus divinitatis, and the trinitarian foundation which supports each one.

Calvin mengatakan bahwa manusia selalu memiliki sense of deity yang tidak dapat dihindari yang senantiasa terukir di dalam pikirannya. ${ }^{87}$ Di dalam diri manusia ada sebuah kesaksian akan keberadaan Tuhan yang terpatri di dalam dirinya. ${ }^{88}$ Pengetahuan manusia akan Tuhan dan akan dirinya ini selalu terpaut (mutual tie). ${ }^{89}$ Dalam titik temu antara Rahner dengan Calvin ini, Rahner lebih lanjut mengatakan bahwa setiap manusia pada dasarnya adalah

${ }^{84}$ Camden M. Bucey, “The Triune Gift of Self: A Reformed Critique of Karl Rahner's Theology of Divine Self-Communication," Ph.D. dissertation (Westminster Theological Seminary, 2014): 146 , https://www.academia.edu/9840681/The Triune Gift of Self A Reformed Critique of Karl Rahners Theology of Divine Self Communication; untuk keterangan makna Vorgriff auf esse sebagai "pre-apprehension of being," lihat halaman 81 .

85 Ibid., 146; Di balik persamaan antara vorgriff dari Rahner dengan sensus divinitatis dari Calvin, ada pula perbedaannya. Meski semua orang mengalami sensus divinitatis, bagi Calvin dan teologi Reformed, keselamatan tetaplah secara eksklusif hanya ada di dalam iman kepada Kristus. Sedangkan Rahner memiliki konsep "anonymous Christian." Ia membuka peluang akan adanya keselamatan bagi mereka yang non-Kristen karena pengalaman akan Tuhan sifatnya universal. Ia mengatakannya demikian, "you have the right to hope that there is a universal salvation which encounters every spiritual person. But you do not have the right to assert theoretically that this salvation will take place for everyone." Karl Rahner, Faith in a Wintry Season: Conversations and Interviews with Karl Rabner in the Last Years of His Life, eds., Paul Imhof and Hubert Biallowons, trans., Harvey D. Egan (New York, NY: Crossroad, 1991), 103. Paul F. Knitter mengatakan bahwa Rahner tidak memberi kepastian bahwa semua orang mengalami keselamatan; Rahner hanya membuka kemungkinannya. "Rahner was just opening a possibility - but one that never before was open for Christians," tulis Knitter. Paul F. Knitter, Introducing the Theologies of Religions (Maryknoll, NY: Orbis Books, 2002), 71.

${ }^{86}$ Bucey, "The Triune Gift of Self," 3.

${ }^{87}$ John Calvin, Institutes of the Christian Religion, I.iii.3.

88 Ibid.

89 Ibid. 
makhluk mistis, homo mysticus. ${ }^{90}$ Di dalam diri manusia ada sebuah kekosongan, ketakutan, kerinduan dan keinginan untuk bersekutu dengan Tuhan yang selama ini ia tidak sadari. ${ }^{91}$ Rahner ingin membawa setiap orang untuk melangkah dari kesadaran akan Tuhan yang tidak ia sadari atau unthematic ini menuju kepada kesadaran akan Tuhan yang disebut sebagai thematic, yang di dalamnya pengalaman akan Tuhan yang sifatnya primitif ini terbangunkan. Rahner mendeskripsikan maksud dan tujuannya sebagai berikut, "to awaken in ourselves this primitive experience of God, the experience of course of God as the ineffable and incomprehensible." 92 Pengalaman tersebut adalah sebuah pengalaman yang membangkitkan dan mengintensifkan "the primordial experience of God living in everyone's heart." ${ }^{\text {"93 }}$

Mary Steinmetz menekankan implikasi positif pemikiran Rahner bagi kehidupan spiritual seseorang. ${ }^{94}$ Menurut Steinmetz, Rahner khawatir dengan orang-orang yang mengalami kekosongan akan Tuhan sehingga ia bertanya, "What are you doing in religion, you human beings...?" Kenyataannya banyak orang percaya belum pernah bersentuhan dengan Tuhan secara pribadi. ${ }^{95}$ Mereka frustasi dengan berbagai doktrin, dogma serta peraturan keagamaan; mereka haus akan sesuatu yang lebih dan bersedia mencoba hal baru. ${ }^{96}$ Steinmetz melihat bahwa Rahner mengedepankan Tuhan sebagai sosok yang selalu dapat didekati oleh manusia meski tetap mempertahankan "the incomprehensibility of Holy Mystery." Baginya, Tuhan adalah "incomprehensible and impenetrable mystery" dan manusia memiliki ciri khas dasar untuk berorientasi radikal terhadap Sang Misteri. ${ }^{98}$ Steinmetz menulis bahwa, "this orientation toward Ultimate Mystery is the foundational

${ }^{90}$ Egan, "The Mystical Theology of Karl Rahner," 43.

91 Karl Rahner, The Practice of Faith: A Handbook of Contemporary Spirituality, eds., Karl Lehmann and Albert Raffelt (New York: Crossroad, 1983), 63.

92 Rahner, The Practice of Faith, 64.

93 Harvey D. Egan, Karl Rahner: Mystic of Everyday Life (New York: Crossroad, 1998), 39. Dengan kata lain, di dalam pengalaman tersebut "we deepen, invigorate and bring to the fore the primal, ontological and transcendental relationship of humanity to God." Jennifer Slater, "'Direct experience of God': A Quest for Refinement and Illumination in Christian Faith and Practice." Studia Historiae Ecclesiasticae, Vol. 36 (2010): 8. http://www.scielo.org.za/pdf/she/v36s1/02.pdf. Lihat juga Ibid., 62-64.

${ }^{94}$ Steinmetz, "Thoughts on the Experience of God," 2.

${ }^{95}$ Karl Rahner, Everyday Faith (New York: Herder and Herder, 1968), 18.

${ }^{96}$ Steinmetz, "Thoughts on the Experience of God," 9.

${ }^{97}$ Ibid., 1. Rahner mengatakan bahwa Tuhan adalah nyata namun pada saat yang sama "this God is incomprehensible mystery." Rahner, The Practice of Faith, 6.

${ }^{98}$ Karl Rahner, The Content of Faith: The Best of Karl Rahner's Theological Writings, eds., Karl Lehmann, Albert Raffelt and Harvey D. Egan (New York: Crossroad, 2000), 45. 
characteristic of being human." ${ }^{99}$ Pada dasarnya, manusia mempunyai orientasi terhadap Misteri. Ada sebuah keterbukaan terhadap Misteri yang adalah akar dari kemanusiaan. Manusia diciptakan untuk mengalami Tuhan yang mengomunikasikan diriNya kepadanya. ${ }^{100}$

Dari perspektif Douglas dan Rhona H. Jacobsen, Rahner dapat dipandang sebagai sosok pemikir yang menghadirkan aspek misteri dalam iman dan oleh sebab itu maka Rahner relevan untuk era pascakebenaran. Perhatian Rahner tertuju kepada apakah seseorang benar-benar mengalami Tuhan. ${ }^{101}$ Seorang murid Rahner, Harvey D. Egan, mengatakan bahwa Rahner ingin menuntun setiap orang kepada mysticism of everyday life. ${ }^{102}$ Rahner ingin membantu setiap individu untuk mengalami Tuhan di dalam kesadarannya sehari-hari. Egan merumuskan relevansi antara teologi mistik Rahner dengan kehidupan seorang Kristen seharihari demikian, ${ }^{103}$

Rahner's theology of the mysticism of everyday life challenges everyone to look more closely at what is actually going on in the depths of their daily lives. What is implicit, hidden, anonymous, repressed, or bursting forth from the center of all we do? To Rahner, there is nothing profane about the depths of ordinary life. Whenever there is a radical self-surrender, an absolute yielding of everything, a surrender to the mystery that embraces all life-there is the Spirit of the crucified and risen Christ, the mysticism of everyday life.

Dalam refleksinya atas spiritualitas dan mistisisme, Rahner menekankan bahwa setiap orang pada dasarnya dipanggil ke dalam hadirat Tuhan dan setiap orang berkesempatan untuk mengalaminya. Sebuah cara untuk menghadirkan sebuah pengalaman akan Tuhan ini adalah melalui doa. Melalui doadoanya, Rahner mengajak pembaca untuk ikut bergumul mengenai

${ }^{99}$ Steinmetz, "Thoughts on the Experience of God," 2. Bagi Rahner, manusia pada dasarnya adalah makhluk spiritual yang senantiasa berorientasi kepada Tuhan. Ia mengatakan demikian, “man’s basic and original orientation towards absolute mystery, which constitutes his fundamental experience of God, is a permanent existential of man as a spiritual subject." Rahner, Foundations of Christian Faith, 52.

100 Steinmetz, "Thoughts on the Experience of God," 2. Rahner rmengatakan bahwa di dalam relasi antara Tuhan dengan manusia, selalu ada "the self-communication of God to man in grace as the transcendental constitution of man." Rahner, Foundations of Christian Faith, 73.

${ }^{101}$ Egan, Karl Rabner, 21.

102 Ibid., 76-77.

103 Ibid. 
siapakah sesungguhnya Tuhan dan manusia. ${ }^{104}$ Ia mengajak pembaca untuk menyadari misteri kehadiran Tuhan di dalam aktivitas kegiatan sehari-hari. ${ }^{105}$ Doa membawa manusia kepada sosok yang transenden yang membuat manusia tidak berdaya di hadapan-Nya. Ia mengajak pembaca untuk bergumul diam di hadapan Tuhan di dalam keheningan. Meskipun doa berisi permohonan kepada Tuhan (petitionary prayer), namun doa sesungguhnya juga adalah sebuah pemberian seluruh keberadaaan diri seseorang kepada Tuhan yang dilakukannya di dalam "trustful submission and love, and in acceptance of the incomprehensible God who is beyond our understanding not only in his essence but also in his free relationship to us and must be accepted as such." ${ }^{106}$ Di dalam doa, seseorang perlu membuka diri terhadap The Ultimate Mystery. ${ }^{107}$ Tulisan-tulisan spiritualnya mengundang para pembaca, bahkan kaum intelektual sekalipun, untuk memasuki sebuah pengalaman misteri. ${ }^{108}$ Unsur misteri ini mendapatkan porsi yang sangat besar sehingga Steinmetz berpendapat bahwa "a major theme of Rahner's experiential theology is the encounter with Mystery as mystery." 100

Paula J. Lee mengingatkan bahwa idealisme Rahner mengenai kehidupan Kristen bukanlah sekadar kehidupan bergereja yang mati secara spiritual yang terkurung dalam ritualisme, legalisme, administrasi, dan kesuaman spiritual yang membosankan. ${ }^{110}$ Kekristenan juga bukanlah sebuah produk massal melainkan sebuah kehidupan dalam pengalaman bersama Tuhan yang unik dan intim bagi setiap individu. Bagi Rahner, setiap orang harus mengalami Tuhan secara langsung.

Rahner senantiasa berupaya menyadarkan pembacanya bahwa pengetahuan teologis mengenai Tuhan semata tidaklah

104 Steinmetz, "Thoughts on the Experience of God," 4.

${ }^{105}$ Egan, Karl Rahner, 58. Bagi Rahner, "mysticicsm occurs in the midst of everyday life, but is hidden and undeclared" dan setiap orang mampu mengalaminya. Rahner, The Practice of Faith, 78.

106 Karl Rahner, The Content of Faith, 88. Doa juga adalah "the act of self-disposal just before the incomprehensibility of God disposes of one, as the reflexion immediately preceding the act of letting oneself fall, after the last of one's own efforts and full of trust, into the infinite Whole which reflexion can never grasp." Rahner, The Practice of Faith, 85.

${ }^{107}$ Steinmetz, "Thoughts on the Experience of God," 7. Melalui doa, seseorang memutuskan untuk menyerahkan dirinya kepada misteri Tuhan, sebuah perjalanan dari pengalaman "unthematic" menuju "thematic" yang Rahner katakan sebagai berikut, "this relationship to God in prayer and decision can and must become thematic and is not just the unthematic, hidden ground of a relationship to the world." Rahner, The Practice of Faith, 121.

108 Steinmetz, "Thoughts on the Experience of God," 9.

${ }^{109}$ Ibid., 12.

110 Paula J. Lee, "Lonely Mystics: A Practical Theological Analysis of Emerging Post-Secular Spiritualities," Ph.D. dissertation (University of Denver, 2016), https://digitalcommons.du.edu/etd/1135. 
cukup. Tulisnya, "Truly, my God, mere knowing is nothing. All it can give us is the sad realization of its own inadequacy. All it can tell us is that through it we can never fully grasp reality and make it a living part of ourselves." 111 Dalam keprihatinannya, Rahner menegaskan bahwa iman Kristen tidak seharusnya hanya disampaikan sebagai indoktrinasi konseptual semata. Lanjutnya, "What Christian faith teaches is never communicated merely by a conceptual indoctrination from without but is and can basically be experienced through the supernatural grace of God as a reality in us." $" 112$

Baginya, kasih Tuhan sangatlah perlu untuk dialami. "Only knowledge gained through experience, the fruit of living and suffering, fills the heart with the wisdom of love," ujarnya. ${ }^{113}$ Seorang Kristen yang tidak pernah mengalami sebuah pengalaman mistik akan menjadi tidak berdaya. "The devout Christian of the future," tulis Rahner, "will either be a 'mystic', one who has experienced 'something,' or he will cease to be anything at all." 114 Dengan demikian, pengalaman akan Tuhan bukanlah sekadar suplemen. Tanpa mengalami Tuhan secara pribadi, Rahner percaya bahwa seorang Kristen akan menjadi lumpuh.

\section{Karya Doa Rahner}

Karya-karya renungan mistik Rahner seperti Encounters with Silence dan Prayers for a Lifetime berpotensi mengatasi kekeringan spiritualitas yang dialami oleh umat Kristen serta menghadirkan unsur emosi, misteri dan kekaguman akan Tuhan. Dalam tulisan mistiknya, Rahner tidak bermaksud memberikan sebuah pengertian akan Tuhan yang komprehensif, melainkan ia ingin mengajak pembacanya menempuh sebuah perjalanan spiritual yang

111 Karl Rahner, Encounters with Silence, trans., James M. Demske (Westminster, MD: Newman, 1966), 29.

112 Karl Rahner, Karl Rabner in Dialogue: Conversations and Interviews, $1965-$ 1982, eds., Paul Imhof and Hubert Biallowons, trans., Harvey D. Egan (New York, NY: Crossroad, 1986), 297 quoted in Steinmetz, "Thoughts on the Experience of God," 7. Rahner mengkritik pemisahan antara nature and grace dalam neo-scholasticism yang ia kemukakan demikian "supernatural grace is a reality of which one knows something through the teaching of faith but which is in itself completely inaccessible and gives no sign of its presence in the conscious, personal life of man." Karl Rahner, "Nature and Grace," Theological Investigations IV, trans., Kevin Symth (Baltimore, MD: Helicon, 1966), 166. Rahner juga mengkritik neo-scholasticism sebagai berikut, "the relationship between nature and grace is conceived in such a way that they appear as two layers so carefully placed that they penetrate each other as little as possible." Rahner, "Nature and Grace," 167.

113 Rahner, Encounters with Silence, 30.

114 Karl Rahner, "Christian Living Formerly and Today," Theological Investigations VII, trans., David Bourke (New York: Herder and Herder, 1971), 15. Lihat juga Harvey D. Egan, "The Mystical Theology of Karl Rahner," 51. 
mendalam. ${ }^{115}$ Seperti tercermin dalam sebuah doa yang dipaparkannya di Encounters with Silence, Rahner berusaha membuat orang-orang yang sibuk dalam rutinitasnya sehari-hari untuk serius memikirkan tentang Tuhan. Doanya berbunyi demikian, ${ }^{116}$

What will become of me, dear God, if my life goes on like this? What will happen to me when all the crates are suddenly swept out of the warehouse? How will I feel at the hour of my death? Then there will be no more daily routine; then I shall suddenly be abandoned by all the things that now fill up my days here on earth.

Di bagian yang lain, ia mengingatkan bahwa Tuhan yang selama ini kita kenal dalam dogmatika tetaplah misterius. Lewat tulisannya, ia ingin membuat pembacanya kembali kagum akan Tuhan dan ingin menyembah-Nya, "When I confess the thrice holy mystery of Your life, so eternally hidden in the abysses of Your Infinity that it leaves behind in creation no sign that we could make out by ourselves, am I not still praising You as the God of my life?"117

Ketika mengalami kekeringan dalam kehidupan doa, Rahner mengajak pembacanya untuk membuka diri secara jujur di hadapan Tuhan demikian, ${ }^{118}$

So often I consider my prayer as just a job I have to do, a duty to be performed. I 'get it out of the way' and then relax, glad to have it behind me. When I'm at prayer, I'm at my 'duty,' instead of being with You. Yes, that's my prayer. I admit it. And yet, my God, I find it hard to be sorry for praying so poorly.

Setelah mengajak pembacanya mengevaluasi diri, Rahner mengajak untuk berseru kepada Tuhan, memohon Tuhan memberikan kesadaran bahwa Ia selalu hadir dalam kehidupan pembacanya. Ketika ia merasa hampa pada waktu berdoa dan merasa tidak didengar oleh Tuhan serta ingin berhenti berdoa, hal tersebut bukan berarti Tuhan tidak mendengarkan doanya. Sesungguhnya ia sedang berhadapan dengan kelemahan-kelemahan dirinya sendiri, "Be merciful to me, my God. When I flee from prayer, it's not that I want to flee from You, but from myself and my own superficiality. I don't want to run away from Your Infinity and Holiness, but from the deserted marketplace of my own soul." 119

\footnotetext{
115 Steinmetz, "Thoughts on the Experience of God," 5.

116 Rahner, Encounters with Silence, 46.

117 Ibid., 4.

118 Ibid., 19.

119 Ibid., 23.
} 
Ketika menghadapi kekeringan spiritual, Rahner tidak memberikan pembacanya penjelasan-penjelasan dogmatik tentang berbagai atribut Tuhan. Sebaliknya, ia mengajak pembacanya dalam kesibukan rutin sehari-hari untuk berseru dan memohon kepada Tuhan agar anugerah kasih Tuhan dapat hadir dan dialami. ${ }^{120}$ Rahner menulis, ${ }^{121}$

This love, which can allow my daily routine to remain routine and still transform it into a home-coming to You, this love only You can give. So, what should I say to You now, as I come to lay my everyday routine before You? There is only one thing I can beg for, and that is Your most ordinary and most exalted gift, the grace of Your Love. Touch my heart with this grace, O Lord.

Dengan nada serupa, di bagian lain Rahner berseru demikian, "Let my heart tremble again and again in grateful surprise at the miracles of Your grace, which is mighty in the midst of weakness." ${ }^{122}$ Dari ekspresi batin Rahner, dapat disimpulkan bahwa dogmatika semata tidaklah cukup. Seperti yang dikemukakan Douglas dan Rhona H. Jacobsen bahwa penghayatan misteri menjadi faktor penting dalam iman di era pascakebenaran ini, namun hal ini telah disadari oleh Rahner di abad ke-20. Rahner membukakan kepada pembaca bahwa misteri Tuhan perlu disambut, dialami dan dirayakan. Rahner ingin mengajak pembacanya mengalami sendiri Tuhan sehingga pembacanya dapat bersama dengannya berseru demikian, “Thanks to Your mercy, O' Infinite God, I know something about You not only through concepts and words, but through experience." ${ }^{123}$ Lewat perjumpaan dengan Tuhan secara pribadi, maka seseorang dapat mengatakan, "Godself I experienced-not human words about God."124

\section{Kesimpulan}

Kalangan Reformed mengenal teologi Calvin sebagai teologi yang kaku, dingin serta mengutamakan intelektualitas semata. Di era pascakebenaran ini, fakta-fakta rasional telah digeser oleh dominasi emosi. Emosi kini lebih berperan besar di dalam

${ }^{120}$ Lihat Karl Rahner, The Mystical Way in Everyday Life: Sermons, Prayers and Essays, trans., Annemarie S. Kidder (Maryknoll, NY: Orbis Books, 2010), 177-78.

${ }^{121}$ Rahner, Encounters with Silence, 52.

122 Ibid., 75.

${ }^{123}$ Karl Rahner, Prayers for a Lifetime, ed., Albert Raffelt (New York: Crossroad, 1984), 17; lihat juga Steinmetz, "Thoughts on the Experience of God," 4.

${ }^{124}$ Karl Rahner, Spiritual Writings: Modern Spiritual Masters Series, ed., Philip Endean (Maryknoll, NY: Orbis Books, 2004), 38 quoted in Steinmetz, "Thoughts on the Experience of God," 6. 
pengenalan akan kebenaran. Bagi Douglas dan Rhonda $H$. Jacobsen, era ini bukanlah untuk dihindari namun untuk dirangkul melalui keterbukaan terhadap kisah dan pengalaman hidup orang lain dengan tujuan untuk memperkaya kehidupan iman seseorang. Hal ini perlu dilakukan karena iman memerlukan transformasi yang dapat menghadirkan unsur perasaan, misteri dan kekaguman. Beriman di era pascakebenaran menjadikan misteri-misteri ilahi bukan suatu hal yang perlu untuk diselidiki, dijawab, ataupun dihindari melainkan menjadi sesuatu yang perlu untuk disambut, disyukuri, dikontemplasikan, serta dialami secara subjektif dan personal.

Karena kehidupan iman di era pascakebenaran berarti berani bertumbuh dalam spiritualitas dengan membuka diri dan melangkah melampaui rasionalitas doktrin, maka penulis menelaah karya Calvin untuk menunjukkan bahwa Calvin sesungguhnya tidaklah bersikap anti terhadap pengalaman religius di dalam kehidupan beriman. Bagi Calvin, pengalaman pribadi justru tidak boleh terpisahkan dari iman. Meski demikian, spiritualitas Calvin yang berpusat pada kesalehan tidak menekankan hadirnya aspek misteri dan kekaguman. Berhubung banyak dari kalangan Reformed menggemari teologi dan eksegesis Calvin namun mencari panduan spiritualitas di tempat lain, maka karya doa mistik Rahner dapat menjadi sarana yang menghadirkan aspek misteri dan kekaguman ini. Ada dua alasan mengapa karya Karl Rahner dapat memberikan kontribusi. Pertama, karya Rahner mengenai preapprehension of God (Vorgriff) dinilai memiliki titik temu dengan sense of deity dari Calvin. Kedua, karya Rahner dinilai selaras dengan tujuan dari Douglas dan Rhonda H. Jacobsen, yakni menghadirkan aspek kekaguman dan misteri di dalam iman. Doa Rahner dapat membantu pembaca untuk mengalami Tuhan sebagai misteri. Meski Tuhan adalah Misteri, namun Ia dapat hadir dalam momenmomen hidup seseorang dan menimbulkan kekaguman akan Dia yang membuat orang tersebut lebih rindu lagi dan mencari kembali pengalaman akan kehadiran Tuhan.

Pembacaan ulang atas karya Calvin diharapkan mampu memberikan ruang bagi keterbukaan bagi pengalaman pribadi di dalam iman yang selama ini terabaikan oleh kalangan Reformed. Membaca ulang karya Calvin memang tidak secara serta-merta mengubah tradisi Calvinisme masa kini yang telah terbentuk secara struktural dan sistematis. Meski demikian, diharapkan dapat mencetuskan dialog lebih lanjut demi mewujudkan sebuah kehidupan iman di mana pengalaman pribadi bersama Tuhan menjadi sebuah hal yang tidak terpisahkan.

\section{Tentang Penulis}

Firdaus Salim baru saja menyelesaikan program studi magister Teologi Integratif di STT Reformed Indonesia. Ia adalah anggota 
dari GKY Jemaat Pluit yang saat ini sedang melayani di GKY Jemaat Greenville.

\section{Daftar Pustaka}

Bartlett, Kenneth R., and Margaret McGlynn. The Renaissance and Reformation in Northern Europe. Toronto: University of Toronto Press, 2014.

Boler, Megan, and Elizabeth Davis. "The Affective Politics of the 'Post-Truth' Era: Feeling Rules and Networked Subjectivity." Emotion, Space and Society, Vol. 27 (2018): 75-85.

Bouwsma, William. John Calvin. New York: Oxford University Press, 1988.

Bucey, Camden M. "The Triune Gift of Self: A Reformed Critique of Karl Rahner's Theology of Divine Self-Communication." Ph.D. dissertation. Westminster Theological Seminary, 2014. https://www.academia.edu/9840681/The Triune Gift of Self A Reformed Critique of Karl Rahners Theology of Divine Self Communication.

Bulman, William J. "Introduction: Enlightment for the Cultural Wars." In God in the Enlightenment. Eds., William J. Bullman and Robert G. Ingram. New York: Oxford University Press, 2016.

Calvin, John. Commentary on the Book of Psalms. Vol. 1. Trans., James Anderson. Grand Rapids, MI: Eerdmans, t.t. https://www.ccel.org/ccel/calvin/calcom08.html.

. Hosea. Vol. 1 of Commentaries on the Twelve Minor Prophets. Trans., John Owen (Grand Rapids, MI: Eerdsmans, t.t.).

https://ccel.org/ccel/calvin/calcom26/calcom26.vii.html. . Institutes of the Christian Religion. Trans., Henry Beveridge. Grand Rapids, MI: Eerdmans, 1989.

. Psalms 93-150. Vol. 4 of Calvin's Commentaries on the Book of Psalms. Trans., James Anderson. Grand Rapids, MI: Baker Books, 1989.

The Epistles to Timothy, Titus and Philemon. Vol. 21 of Calvin's Commentaries. Trans., William Pringle. Grand Rapids, MI: Baker Books, 1989.

Canlis, Julie. Calvin's Ladder: A Spiritual Theology of Ascent and Ascension. Grand Rapids, MI: Eerdmans, 2010.

Challies, Tim. "The Boundaries of Evangelicalism." Challies, May 8, 2013. http://www.challies.com/articles/the-boundariesof-evangelicalism.

Chapel, Bryan. Christ-Centered Worship. Grand Rapids, MI: Baker Academic, 2009.

Chin, Clive S. "Calvin, Mystical Union, and Spirituality." Torch Trinity Journal, Vol. 6 (2003): 183-209. www.ttgst.ac.kr/upload/ttgst resources13/20123-164.pdf. 
Davies, Stephen T. Rational Faith: A Philosopher's Defense of Christianity. Oxford: InterVarsity Press, 2016.

DeHoff, Susan L. Psychosis or Mystical Religious Experience? A New Paradigm Grounded in Psychology and Reformed Theology. Boston: Palgrave Macmillan, 2018.

Egan, Harvey D. Karl Rahner: Mystic of Everyday Life. New York: Crossroad, 1998.

. "The Mystical Theology of Karl Rahner." The Way, Vol. 52, No. 2 (2013): 43-62. https://www.theway.org.uk/back/522egan.pdf.

Farnsworth, Kirk E. Wholehearted Integration: Harmonizing Psychology and Christianity through Word and Deed. Grand Rapids, MI: Baker Book House, 1985.

Ford, Patrick. Faith Isn't Blind: Logical Arguments from Science, History, and Philosophy that God Really Exists. Bloomington, IN: Westbow, 2016.

Grier, Peter, and Story Hinckley. "Two Ways to Read the Story." The Christian Science Monitor, 2020. https://www.csmonitor.com/USA/Politics/2020/1119/Po st-truth-politics-As-Trump-pushes-fraud-partisans-picktheir-own-reality.

Horton, Michael. Calvin on the Christian Life: Glorifying and Enjoying God Forever. Wheaton, IL: Crossway, 2014.

Jacobsen, Douglas, and Rhonda Hustedt Jacobsen. "Faith and Learning in a Post-Truth World." Journal of College and Character, Vol. 19, No. 2 (2018): 93-100. https://www.tandfonline.com/doi/full/10.1080/2194587X. 2018.1445645.

James, William. The Varieties of Religious Experience: A Study in Human Nature. Centenary Edition. New York: Routledge, 2002.

Johnson, Arthur L. Faith Misguided: Exposing the Dangers of Mysticism. Chicago, IL: Moody Press, 1988.

De Jonge, Christiaan. Apa Itu Calvinisme. Jakarta: BPK Gunung Mulia, 2008.

Keller, Timothy. Making Sense of God: Finding God in the Modern World. New York: Penguin Books, 2018.

Kelsey, Morton. Foreword to Reformed Spirituality by Howard L. Rice. Louisville, KY: Westminster John Knox, 1991.

Knitter, Paul F. Introducing the Theologies of Religions. Maryknoll, NY: Orbis Books, 2012.

Kyung Sik Joo. "The Nature and Characteristics of Calvin's Piety." Journal of Theological Reflections, Vol. 2 (2016): 155-190. http://scd.edu.au/wp-

content/uploads/sites/2/2017/04/06-주경식155-190.pdf.

Lee, Paula J. "Lonely Mystics: A Practical Theological Analysis of Emerging Post-Secular Spiritualities." Ph.D. dissertation. 
University of Denver, 2016. https://digitalcommons.du.edu/etd/1135/.

Magnis-Suseno, Franz. "Philosophy, A Challenge to Post-Truth, also in Indonesia." Jurnal Filsafat, Vol. 30, No. 1 (2020): 1-22. https://jurnal.ugm.ac.id/wisdom/article/view/53671/2716 $\underline{6}$.

McCracken, Brett. The Wisdom Pyramid: Feeding Your Soul in a PostTruth World. Wheaton, IL: Crossway, 2021. Kindle.

McNeill, John T. Introduction to Institutes of the Christian Religion by John Calvin. Ed., trans., Ford Lewis Battles. Philadelphia, PA: Westminster Press, 1960

Packer, J. I. “'Sola Scriptura' in History and Today." God's Inerrant Word: An International Symposium on the Trustworthiness of Scripture. Ed., John Warwick Montgomery. Minneapolis, MN: Bethany, 1974.

Parnell, Jonathan. "A System for Praying." Desiring God. January 1, 2012. https://www.desiringgod.org/articles/a-system-forpraying-in-2012.

Peters, Michael A. "Education in a Post-Truth World." Educational Philosophy and Theory, Vol. 49, No. 6 (2017): 563-566. https://www.tandfonline.com/doi/full/10.1080/00131857. 2016.1264114.

Rahner, Karl. "Christian Living Formerly and Today." Theological Investigations VII. Trans., David Bourke. New York: Herder and Herder, 1971.

- Encounters with Silence. Trans., James M. Demske.

Westminster, MD: Newman, 1966.

. Everyday Faith. New York: Herder and Herder, 1968.

. Faith in a Wintry Season: Conversations and Interviews with Karl

Rabner in the Last Years of His Life. Eds., Paul Imhof and Hubert Biallowons. Trans., Harvey D. Egan. New York: Crossroad, 1991.

. Foundations of Christian Faith: An Introduction to the Idea of Christianity. Trans., William V. Dych. New York: Crossroad, 1978.

. Karl Rahner in Dialogue: Conversations and Interviews, $1965-$ 1982. Eds., Paul Imhof and Hubert Biallowons. Trans., Harvey D. Egan. New York: Crossroad, 1986.

. "Nature and Grace." Theological Investigations IV. Trans., Kevin Symth. Baltimore, MD: Helicon, 1966.

- Prayers for a Lifetime. Ed., Albert Raffelt. New York: Crossroad, 1984.

The Content of Faith: The Best of Karl Rabner's Theological Writings. Eds., Karl Lehmann, Albert Raffelt and Harvey D. Egan. New York: Crossroad, 2000.

The Mystical Way in Everyday Life: Sermons, Prayers and Essays. Trans., Annemarie S. Kidder. Maryknoll, NY: Orbis 
Books, 2010.

. The Practice of Faith: A Handbook of Contemporary Spirituality. Eds., Karl Lehmann and Albert Raffelt. New York: Crossroad, 1983.

Rice, Howard L. Reformed Spirituality. Louisville, KY: Westminster John Knox, 1991.

Sire, James. W. Echoes of a Voice: We are not Silent. Eugene, OR: Wipf and Stock, 2014.

Slater, Jennifer. "Direct experience of God': A Quest for Refinement and Illumination in Christian Faith and Practice." Studia Historiae Ecclesiasticae 36 (2010): 1-15. http://www.scielo.org.za/pdf/she/v36s1/02.pdf.

Sproul, R. C. The Soul's Quest for God: Satisfying the Hunger for Spiritual Communion with God. Phillipsburg, NJ: P\&R Publishing, 2003.

Steinmetz, Mary. "Thoughts on the Experience of God in the Theology of Karl Rahner: Gifts and Implications." Lumen et Vita, Vol. 2, No. 1 (2012): 1-14. https://ejournals.bc.edu/index.php/lumenetvita/article/vie $\mathrm{w} / 1900$.

Tamburello, Dennis E. Union with Christ: John Calvin and Mysticism of St. Bernard. Louisville: Westminster John Knox, 1994. 